radoslaw.jez@ue.katowice.pl

Anna Konieczko

anna.konieczko@ue.katowice.pl

Małgorzata Kwiatkowska

malgorzata.kwiatkowska@ciniba.edu.pl

Biblioteka Główna

Uniwersytetu Ekonomicznego w Katowicach

\title{
JAKOŚĆ USŁUG INFORMACYJNYCH BIBLIOTEKI AKADEMICKIEJ JAKO WAŻNY ELEMENT GOSPODARKI OPARTEJ NA WIEDZY
}

\begin{abstract}
Universities retrieve a very important role in the creation of a knowledge-based economy on innovation sectors, regions and enterprises. These institutions are increasingly using new technologies of information to heighten awareness about the advisability of using them to create a new, competitive economic reality.

Expectations of the science sector are associated with the processes of knowledge building and their transfer to the economy and creating conditions conductive to the learner's regions.

University libraries fulfill a particular role in the codification and sharing of information and the creation of conditions for which they were obtained by different users. The quality of services offered by these entities is therefore a key aspect of the user to zoom in and familiar with modern technologies. The article deals with the subject of the quality of information services carried out in an academic library as an essential part of the strategy of innovation and knowledge-based economy, and also proposes a cost of quality of such services.
\end{abstract}

Słowa kluczowe: usługi informacyjne, koszty jakości, koszty usług

\section{Wstęp}

Środowisko akademickie nieustannie poszukuje informacji, aby móc prowadzić badania, tworzyć i przekazywać wiedzę, budować nową jakość nauki i kształcenia. Społeczeństwo, które dzieli się informacjami i wiedzą, przyczynia się do kreowania gospodarki opartej na wiedzy (GOW). Ważna jest przy tym odpowiednia jakość przekazywanych informacji i sprawność informacyjna osób, które zawodowo zajmują się realizowaniem usług informacyjnych. Wśród nich można wskazać na bibliotekarzy/pracowników informacji w bibliotekach akademickich, którzy mają największy wpływ na jakość usług realizowanych przez te instytucje. 


\section{Gospodarka oparta na wiedzy - zarys problemu w odniesieniu do szkolnictwa wyższego}

Na rozwój społeczno-gospodarczy regionów mają obecnie wpływ: rosnąca rola kapitału ludzkiego oraz uznanie roli wiedzy i technologii w gospodarce. Sektor usług wiedzy to jest: edukacji, komunikacji i informacji oraz produkcja w branżach wysokich technologii pokazują, że ponad 50\% PKB w głównych gospodarkach krajów OECD (Organization for Economic Cooperation and Development $)^{1}$ oparta jest na wiedzy oraz technologiach informatycznoinformacyjnych. Nie bez znaczenia w budowaniu, jak i w całym procesie kreowania gospodarki wiedzy, jest system szkolnictwa wyższego. To właśnie działania w tym obszarze są przyczynkiem do tworzenia wysokich technologii, rozwoju wiedzy i wdrażania prowadzonych badań naukowych do praktyki gospodarczej.

Na początku lat osiemdziesiątych XX w. Alvin Toffler przedstawił obraz nowej rzeczywistości gospodarczej, jako erę wiedzy, informacji i technologii, która stała się początkiem zmian w zakresie tworzenia i podziału wytworzonych dóbr i usług, jak również wprowadzania w skostniałe struktury organizacyjne nowych elementów informacyjnych i technologicznych ${ }^{2}$.

Gospodarka oparta na wiedzy oznacza wykorzystanie technologii informacyjnych i komunikacyjnych przez sektor publiczny i prywatny w celu podnoszenia innowacyjności oraz konkurencyjności kraju, regionu, czy też lokalnego obszaru.

Warunkami uczestniczenia w GOW są między innymi prężnie działające sieci ośrodków badawczych, uniwersytetów zdolnych do wykorzystania, asymilacji i tworzenia nowej wiedzy oraz społeczeństwo informacyjne, które powinno posiadać i rozwijać swoje umiejętności w zakresie tworzenia i wykorzystywania wiedzy ${ }^{3}$.

Uczelnie wyższe dzięki udziałowi w konsorcjach krajowych i zagranicznych, inwestowanie w wiedzę, odpowiednią infrastrukturę kształcenia (dostęp do nowych technologii i multimedialnych zasobów) dają możliwości rozwoju pracownikom naukowym i studentom - co w konsekwencji pozwala im dobrze wkomponować się w sytuację na rynku pracy, a także przybliżają możliwości implementacji swoich badań do przestrzeni gospodarczej, pozwalają łączyć odkrycia naukowe z elementami gospodarki, jak również korzystać z dokonań naukowców z innych regionów świata.

Wiedza i kompetencje w ujęciu strategicznym udostępniane są $\mathrm{w}$ ramach tworzonych sieci, w których know-how ma dominujące znaczenie. Gospodarki krajowe coraz bardziej funkcjonują $\mathrm{w}$ ramach hierarchii sieci, a tempo rozwoju

${ }^{1}$ Zob. OECD Science, Technology and Industry Outlook 2014, [dostęp: 11.05.2015], http://www.oecd.org/sti/oecd-science-technology-and-industry-outlook-19991428.htm.

${ }^{2}$ A. Toffler, Trzecia fala, Poznań 2006, s. 35-37, 320-329.

${ }^{3}$ Por. D. Makulska, Kluczowe czynniki rozwoju w gospodarce opartej na wiedzy, „Prace i Materiały Instytutu Rozwoju Gospodarczego / Szkoła Główna Handlowa” 2012, nr 88, s. 177. 
nauki decyduje o zmianach i wzroście wskaźników makroekonomicznych. Gospodarka wiedzy, a dalej społeczeństwo sieci, stwarzają szanse poprawy warunków społeczno-ekonomicznych poprzez wykorzystanie zasobów dostępnych w Internecie. Ogólnoświatowe tendencje pokazują systematyczny wzrost zainteresowania inwestycjami $\mathrm{w}$ branże wysokich technologii. Jest to ściśle powiązane z zatrudnianiem pracowników wysoko wykwalifikowanych, gdyż sprawne wykorzystanie nowoczesnych technologii przyczynia się do wzrostu wydajności ${ }^{4}$.

W warunkach GOW bardzo ważnym problemem jest zarządzanie informacją, które powinno przekładać się na wzrost wartości dodanej. Według Michaela E. Portera, wartość dodana to suma kosztów wykonania działań wartościowych i marży. Osiągnięcie wysokiej wartości dodanej jest możliwe, gdy instytucje czy przedsiębiorstwa posiadają dobrze koordynowane procesy ${ }^{5}$. Doskonalenie łańcucha wartości $\mathrm{w}$ odniesieniu do szkolnictwa wyższego przejawia się w lepszym dostosowaniu realizowanych działań do potrzeb rynku. Aby zatem łańcuch wartości mógł być wykorzystany do działań rynkowych, system nauki i szkolnictwa wyższego powinien stworzyć możliwości wzajemnego przenikania wiedzy i badań oraz sygnałów ze strony podmiotów gospodarczych dotyczących zapotrzebowania na nowe badania czy kierunki kształcenia. Uczelnie wyższe powinny być odpowiedzialne za kształcenie kompetentnej kadry dla gospodarki, pracowników umiejących stosować najnowocześniejsze technologie w praktyce zawodowej. Instytucje te uczestniczą w procesie transferu innowacji, technologii i nowoczesnych rozwiązań, które umożliwiają rozwój społeczny i gospodarczy. Szkoły wyższe są organizacjami, których kapitał intelektualny odgrywa największą rolę, a ich głównym produktem są wiedza i umiejętności absolwentów ${ }^{6}$. Finasowanie kierunków badań zamawianych jest ciągle niewystarczające. Polska wydaje z budżetu państwa trzy razy mniej środków (w relacji do PKB) na działalność naukową i rozwojową niż inne kraje Unii Europejskiej. Pozytywnym działaniem, pomimo relatywnie złego stanu finansów publicznych, było podjęcie decyzji o zwiększeniu środków budżetowych na naukę w 2012 r. Nakłady na naukę w budżecie Ministerstwa Nauki i Szkolnictwa Wyższego wyniosły około 6,37 mld PLN (w tym środki UE w wysokości 1,3 mld PLN), to jest 18,36\% więcej niż w ustawie budżetowej na $2011 \mathrm{r}^{7}$ Systematyczne zwiększanie środków na szkolnictwo wyższe obserwujemy również w kolejnych latach. W 2015 r. nakłady na naukę wyniosą 7 mld

\footnotetext{
${ }^{4}$ Zob.: Nowa teoria wzrostu, która pokazuje wzajemne powiązania pomiędzy wiedzą, technologią a wydajnością i wzrostem gospodarczym.

${ }^{5}$ E. Skrzypek, M. Hofman, Zarzadzanie procesami w przedsiębiorstwie. Identyfikacja, pomiar, usprawnianie, Warszawa 2010, s. 46-50.

${ }^{6}$ R. Przybyszewski, Kapitat ludzki w procesie ksztaltowania gospodarki opartej na wie$d z y$, Warszawa 2007, s. 100-102.

${ }^{7}$ E. Jurczak-Pejko, Ksztatcenie na poziomie wyższym a potrzeby gospodarki (opartej na) wiedzy, „Studia Ekonomiczne / Uniwersytet Ekonomiczny w Katowicach” 2013, nr 131, s. 105.
} 
$438 \mathrm{mln}$ zł milionów złotych, to jest o 10,2 proc. więcej niż w 2014 r. ${ }^{8}$ Poziom szkolnictwa wyższego i rozwój gospodarki wiedzy stwarzają wyzwania zarówno dla polityki krajowej, jak i wielostronnego podejmowania decyzji w ujęciu międzynarodowym. Nauka i badania mają coraz większe znaczenie w dzisiejszym świecie, dlatego też umiejętne wykorzystanie tych instrumentów może przyczynić się do rozwoju, nie tylko w ujęciu makroekonomicznym danego regionu, ale także do budowania kapitału ludzkiego, tożsamości społecznej i podnoszeniu jakości własnych umiejętności i kwalifikacji.

Biblioteki akademickie, jako jednostki organizacyjne uczelni wyższych, oferują działania odnoszące się do rozwoju społeczeństwa informacyjnego', a tym samym kreowania pożądanych zachowań informacyjnych, udostępniają zasoby informacyjne służące tworzeniu wiedzy, a w konsekwencji zaznaczają swoje miejsce w budowaniu gospodarki opartej na wiedzy.

\section{Usługi bibliotek akademickich ukierunkowane na gospodarowanie informacją i wiedzą}

Biblioteka akademicka jest instytucją usługową, działającą w strukturze uczelni wyższej, ukierunkowaną na zaspokajanie potrzeb informacyjnych jej użytkowników. To instytucja pośrednicząca $\mathrm{w}$ różnych formach komunikowania się oraz gromadząca i udostepniająca zróżnicowane zasoby (książki, czasopisma, źródła elektroniczne).

Kształtowanie i realizacja usług informacyjno-bibliotecznych jest uzależniona od potrzeb społeczności akademickiej, uczelnianych programów kształcenia, trendów rozwojowych oraz wymagań rynkowych i ustawowych.

Usługę informacyjno-biblioteczną można zdefiniować jako działania, czynności, procesy, które dzięki wykorzystaniu specjalistycznych kompetencji bibliotekarzy (wiedzy i umiejętności) oraz zasobów informacyjnych i elementów infrastrukturalnych biblioteki (sprzęt, lokal, dostęp do Internetu) mogą przynosić korzyści innym podmiotom ${ }^{10}$. Korzyści te mogą mieć charakter ekonomiczno-społeczny, jak na przykład znalezienie pracy, wspólne spotkania tematyczne sprzyjające realizowaniu pasji, zaoszczędzenie czasu w procesie edukacji lub badań naukowych, wspomaganie turystyki miejskiej. Usługi te są przede wszystkim jednym z rodzajów usług edukacyjnych, których sposób realizacji zależy w dużej mierze od jakości pracy personelu bibliotecznego.

${ }^{8}$ Resort nauki: w 2015 r. naktady na naukę wyższe o $690 \mathrm{mln}$ zt., Serwis Nauka w Polsce, [dostęp: 08.04.2015], http://naukawpolsce.pap.pl.

${ }^{9} \mathrm{~W}$ społeczeństwie informacyjnym, działania człowieka sprowadzają się do tworzenia, asymilacji i akomodacji informacji oraz wykorzystywania jej do realizacji celów zawodowych $\mathrm{i}$ osobistych, zob. E. Ziemba, R. Żelazny, Społeczeństwo informacyjne - projekty i przedsięwzięcia $w$ województwie śląskim, ,Nierówności Społeczne a Wzrost Gospodarczy / Uniwersytet Rzeszowski" 2013, nr 32, s. 555.

${ }^{10}$ S.L. Vargo, R.F. Lusch, Evolving to a new dominant logic for marketing, ,Journal of Marketing" 2004, t. 68, nr 1, s. 2 z modyfikacjami; Uniwersalny słownik języka polskiego, red. S. Dubisz, Warszawa 2003, s. 281 z modyfikacjami. 
Wiele czynników, takich jak: umiędzynarodowienie usług, postęp w technologii komunikacyjno-informacyjnej, indywidualizacja potrzeb oraz cyfryzacja przestrzeni edukacyjnej i naukowej, włącza bibliotekę akademicką w działalność sektora usług opartych na zaawansowanej wiedzy (KIBS Knowledge Intensive Business Services). Pojęcie KIBS stosuje się w odniesieniu do usług, których rezultatem jest tworzenie, akumulowanie lub rozpowszechnianie wiedzy ${ }^{11}$. Usługi te opierają się na profesjonalnej i specjalistycznej wiedzy, stanowią źródło informacji i wiedzy dla ich użytkowników (na przykład w postaci działalności szkoleniowej, doradczej, opracowanych raportów) lub mogą wpływać na procesy przetwarzania informacji i generowania własnej wiedzy przez klientów. Ich głównymi odbiorcami są przedsiębiorstwa oraz organizacje z sektora prywatnego i publicznego. Biblioteki akademickie wpisują się w kreowanie tego typu usług, gdyż zadaniem bibliotekarzy jest pomoc, nie tylko pojedynczym użytkownikom, ale również organizacjom, w poszukiwaniu rozwiązań problemów związanych z pozyskiwaniem danych, informacji, zasobów wiedzy, przy wykorzystaniu przez nich profesjonalnej wiedzy i doświadczenia zawodowego.

Kształtowanie i rozwój kompetencji informacyjnych osób korzystających z biblioteki jest tą aktywnością biblioteki akademickiej, która przyczynia się do świadomego uczestniczenia w procesie budowania gospodarki opartej na wiedzy. Umiejętności wyszukiwania, gromadzenia, selekcji i analizy informacji oraz sprawnego korzystania $\mathrm{z}$ bogactwa zasobów informacyjnych znajdujących się $\mathrm{w}$ bibliotekach, ośrodkach informacji czy udostępnianych przez różne media stają się podstawą pełnego uczestnictwa w społeczeństwie informacyjnym ${ }^{12}$.

Użytkownicy systemu informacyjnego uczelni, aby w sposób efektywny wyszukiwać informacje (to znaczy znaleźć informacje relewantne, będące wartościowym źródłem, które można wykorzystać), potrzebują pomocy profesjonalistów - merytorycznych pracowników biblioteki. Umożliwiają oni i ułatwiają dostęp do zasobów oraz uczestniczą w procesie kształcenia kompetencji informacyjnych użytkowników, pozwalających na sprawne (swobodne) i efektywne poruszanie się w licznych serwisach informacyjnych, bazach danych, katalogach bibliotecznych ${ }^{13}$.

${ }^{11}$ Za: A. Skórska, Wiedzochłonne uslugi biznesowe w Polsce i innych krajach Unii Europejskiej, Katowice 2012, s. 94.

${ }^{12}$ E.B. Zybert, Wstęp, [w:] Czas przemian, czas wyzwań: rola bibliotek i ośrodków informacji $w$ procesie ksztaltowania kompetencji wspótczesnego człowieka, red. J. Jasiewicz, E.B. Zybert, Warszawa 2014, s. 10.

${ }^{13}$ A. Konieczko, Korzyści z kształcenia umiejętności informacyjnych użytkowników biblioteki (przyktad Biblioteki Głównej Akademii Ekonomicznej im. Karola Adamieckiego w Katowicach), [w:] Seria III: ePublikacje Instytutu INiB UJ, red. Maria Kocójowa, Nr 5. Biblioteka: klucz do sukcesu użytkowników, s. 81, [dostęp: 21.03.2015], http://eprints.rclis.org/13696/1/ konieczko-n.pdf. 
W literaturze information literacy definiuje się jako kompetencje, dzięki którym dana osoba jest zdolna rozpoznać, czy informacja jest potrzebna i ma umiejętność jej zlokalizowania, oceny oraz efektywnego wykorzystania ${ }^{14}$.

Zakres kompetencji informacyjnych obejmuje: rozpoznanie potrzeb informacyjnych i sposobów ich zaspokojenia, tworzenie strategii wyszukiwania informacji, lokalizowanie i dostęp do informacji, porównanie i ocena informacji uzyskanej z różnych źródeł, organizowanie, zastosowanie i prezentowanie informacji innym zgodnie $\mathrm{z}$ określoną sytuacją, syntezę i tworzenie nowych zasobów wiedzy na podstawie istniejącej informacji ${ }^{15}$.

A zatem kompetencje informacyjne to umiejętność zdefiniowania potrzeby informacyjnej w kontekście konkretnego problemu informacyjnego, rozważenie możliwych źródeł informacji, dokonanie wyboru i lokalizacja najwłaściwszego z nich oraz wyszukanie informacji wraz z oceną. Następnie zadecydowanie o przydatności informacji, umiejętność przekazania jej innym oraz ocena procesu wyszukiwawczego i stworzenie nowej wiedzy.

Do zadań dydaktycznych biblioteki akademickiej, mających na celu rozwój kompetencji informacyjnych jej użytkowników należą ${ }^{16}$ między innymi:

- informowanie za pomocą profesjonalnej strony internetowej o dostępności tematycznych i multidyscyplinarnych źródeł informacji;

- $\quad$ przygotowanie studentów rozpoczynających studia do korzystania z bibliotek naukowych (uczelni macierzystej, jak również innych miejscowych szkół wyższych);

- $\quad$ organizowanie zajęć dla studentów i innych zainteresowanych z zakresu korzystania z biblioteki akademickiej i jej tradycyjnych oraz elektronicznych zasobów;

- $\quad$ pomoc absolwentom w systematycznym doskonaleniu zawodowym, poprzez oferowanie im dostępu do bieżącej literatury branżowej;

- organizowanie warsztatów dla uczniów szkół średnich, zwłaszcza klas maturalnych w kontekście nauki wyszukiwania informacji;

- $\quad$ organizowanie warsztatów wyszukiwania informacji w zasobach Internetu dla pracowników instytucji publicznych.

W konsekwencji do usług związanych z pozyskiwaniem informacji, a co za tym idzie wiedzy, należą ${ }^{17}$ :

- profesjonalna strona internetowa biblioteki, prezentująca i omawiająca usługi biblioteczne;

\footnotetext{
${ }^{14}$ L. Derfert-Wolf, Information literacy - koncepcje i nauczanie umiejętności informacyjnych, ,Biuletyn EBIB” 2005, nr 1 (62), [dostęp: 21.03.2015], http://ebib.oss.wroc.p1/2005/62/ derfert.php

${ }^{15}$ W oparciu o model SCONUL, zob. L. Derfert-Wolf, op. cit.

${ }^{16}$ Zob. B. Grala, Dydaktyka biblioteczna w uczelniach medycznych $w$ aspekcie ksztaltowania się edukacji informacyjnej, „Praktyka i Teoria Informacji Naukowej i Technicznej” 2007, nr 1, s. 31 .

${ }^{17}$ D. Konieczna, Ustugi bibliotek akademickich ukierunkowane na potrzeby zdalnego i ustawicznego ksztatcenia, [w:] Nowoczesna Biblioteka Akademicka. Olsztyn 20-21 maja 2004. Dane tekstowe, EBIB Materiały konferencyjne 2004, nr 9, [dostęp: 20.03.2015], http://www. ebib.pl/publikacje/matkonf/nba/konieczna.danuta.php.
} 
- $\quad$ szkolenia dla użytkowników w zakresie korzystania z usług bibliotecznych i wyszukiwania informacji;

- zapewnienie dostępu do zasobów i usług informacyjno-bibliotecznych w bibliotece oraz poza nią:

- $\quad$ zdalny dostęp do informacji dla wszystkich studiujących i pracujących na uczelni powinien być jednolity i spójny, powinien zapewniać możliwość korzystania z subskrybowanych elektronicznych baz danych, e-książek, e-czasopism;

- pośredniczenie w dostępie do otwartych zasobów edukacyjnych powszechnie i publicznie dostępnych w Internecie na zasadzie wolnych licencji - wskazanie użytkownikom o możliwości skorzystania z takich materiałów;

- dostępny dla wszystkich zainteresowanych katalog komputerowy, zapewniający informacje o zbiorach bibliotecznych;

- zorganizowanie i zapewnienie dostępu do repozytoriów wiedzy tworzonych w uczelni wyższej;

- $\quad$ wypożyczenia międzybiblioteczne i usługi dostarczania dokumentów $\mathrm{w}$ formie elektronicznej i związane $\mathrm{z}$ tym porozumienia między bibliotekami akademickimi lub publicznymi w celu wzajemnego wypożyczania materiałów elektronicznych ze względu na niewystarczające zasoby macierzystej biblioteki;

- zdalne udzielanie informacji, wykorzystujące opcję czat, e-mail, fax, telefon;

- $\quad$ stworzenie przestrzeni i odpowiednich warunków do pracy w bibliotece (infrastruktura, wyposażenie i organizacja miejsca);

- latwy dostęp do komputerów i oprogramowania;

- $\quad$ korzystanie z narzędzi technologicznych wspomagających aktywne wyszukiwanie informacji.

Nabycie kompetencji informacyjnych jest efektem współpracy pomiędzy pracownikami informacji, bibliotekarzami i całym środowiskiem akademickim.

Usługi informacyjne Biblioteki Głównej Uniwersytetu Ekonomicznego w Katowicach ukierunkowane na podnoszenie kompetencji informacyjnych jej użytkowników realizowane są w Bibliotece od wielu lat. We wrześniu 2012 r., Biblioteka zmieniła swoją siedzibę i wspólnie z Biblioteką Uniwersytetu Śląskiego funkcjonuje w nowoczesnym budynku CINiBA (Centrum Informacji Naukowej i Biblioteka Akademicka). Nowa lokalizacja wpłynęła nie tylko na zmianę kultury organizacyjnej Biblioteki, ale przede wszystkim otwarła nowe możliwości realizacji usług informacyjnych oferowanych środowisku naukowemu obydwu Uczelni. Podnoszenie kompetencji informacyjnych użytkowników jest obecnie dużo prostsze i efektywniejsze. Forma i zakres zadań dydaktycznych nakierowanych na ten proces obejmuje pełny zakres usług wymienionych powyżej, począwszy od szkoleń z zakresu przysposobienia bibliotecznego dla studentów I roku studiów, do prowadzenia profesjonalnego serwisu informacyjnego. W nowych warunkach zwiększył się też dostęp do źródeł 
informacji naukowej, a liczba oferowanych imprez, warsztatów, szkoleń jest również większa niż w okresie, gdy Biblioteki funkcjonowały oddzielnie. Rocznie w CINiBA organizowanych jest średnio około 1000 różnego typu wydarzeń, spotkań, wycieczek, prezentacji, szkoleń i warsztatów. Doskonałe warunki lokalowe i nowoczesne rozwiązania informatyczne pozwalają na rozwijanie i monitoring kompetencji nabywanych przez użytkowników.

\section{Jakość usług informacyjnych i propozycja kosztów jakości ich realizacji}

Jakość to zdolność biblioteki do wypełniania celu, do zaspokajania stwierdzonych i przypuszczalnych potrzeb, a więc umożliwienie, dostarczenie tego, do czego dana usługa lub produkt są przeznaczone ${ }^{18}$.

Badacze Lee Harvey i Diana Green dokonali analizy jakości w odniesieniu do szkolnictwa wyższego. W ogólnym stwierdzeniu, uznali oni, że po pierwsze jakość oznacza różne rzeczy dla różnych osób, a po drugie, jest ona zależna od procesów i rezultatów. Definiowanie jakości powinno wiązać się z określeniem pragmatycznych kryteriów, które odzwierciedlają aspekty jakości i pomagają przy jej ocenie ${ }^{19}$. Według nich jakość można rozumieć jako wyjątkowość, perfekcję, sprawność w realizacji celu, wartość finansową, transformację $^{20}$. Adaptując ich twierdzenia dotyczące jakości w odniesieniu do bibliotek akademickich można traktować:

- jakość jako wyjątkowość: biblioteka zapewnia dostęp do publikacji i innych wytworów myśli ludzkiej poprzez tradycyjne i/lub elektroniczne źródła informacji, oferując przy tym wysoki standard obsługi każdego użytkownika;

- $\quad$ jakość jako perfekcja: procesy biblioteczne powinny być wolne od błędów - na każdym etapie procesu książki pozyskanej przez bibliotekę - od momentu zakupu, poprzez akcesję, opracowanie zgodne z normami opisu bibliograficznego, kodowanie, aż do udostępniania użytkownikom, a także udzielanie pełnej i konkretnej informacji - niedopuszczenie do zjawiska szumu informacyjnego;

- jakość jako sprawność w realizacji celu - wyszukiwanie relewantnych informacji w katalogach i bazach danych dla konkretnego odbiorcy, szybkość obsługi związanej z procesem zamówienia i wypożyczenia książki, dobór odpowiednich metod i narzędzi do realizacji usługi;

${ }^{18}$ E.B. Zybert, Jakość $w$ działalności bibliotek. Oceny, pomiary, narzędzia, Warszawa 2007, s. 21.

${ }^{19}$ L. Harvey, D. Green, Defining quality, „Assessment and Evaluation in Higher Education" 1993, Vol. 18, Issue 1, [dostęp: 06.05.2012], http://web.ebscohost.com/ehost/detail? $\mathrm{vid}=4 \& \mathrm{hid}=106 \& \mathrm{sid}=\mathrm{c} 080 \mathrm{f} 621-6 \mathrm{f} 90-4 \mathrm{f} 81-\mathrm{a} 120-4 \mathrm{af} 89419 \mathrm{ea} 33 \% 40$ sessionmgr $113 \& \mathrm{bdata}=\mathrm{Jm} \times \mathrm{h}$ bmc9cGwmc210ZT1laG9zdC1saXZl\#db=a9h\&AN=970708527.

${ }^{20}$ L. Harvey, D. Green, op. cit.; K. Leja, Instytucja akademicka. Strategia, efektywność, jakość, Gdańsk 2003, s. 24. 
- jakość jako relacja do ceny - odpłatne przygotowanie ważnych zestawień tematycznych, bibliograficznych, kserokopii lub skanu dokumentów najtaniej i w możliwie najszybszym czasie;

- jakość jako transformacja - prowadzenie szkoleń informacyjno-bibliotecznych dla użytkowników w taki sposób, aby informacje i wiedza z nich płynące odegrały istotną rolę w późniejszym procesie edukacji oraz wykształciły umiejętności wyszukiwania informacji.

We wszystkich wyżej wymienionych aspektach jakości usług wyróżnia się kapitał intelektualny biblioteki akademickiej. Kapitał intelektualny to efekt synergii zasobów niematerialnych, które we współdziałaniu z zasobami materialnymi przyczyniają się do prawidłowego funkcjonowania organizacji ${ }^{21}$. Strukturę kapitału intelektualnego tworzą: kapitał ludzki, kapitał strukturalny/ organizacyjny i kapitał relacyjny. Na kapitał intelektualny biblioteki akademickiej składają się:

- personel merytoryczny i pomocniczy: wiedza, umiejętności, doświadczenie, postawy, talenty, zdolności, zasób zdrowia i energii, sprawność intelektualna, wartości (kapitał ludzki);

- $\quad$ kolekcja książek, bazy danych, serwisy naukowe, regulaminy, normy i procedury, kultura organizacyjna, systemy informatyczne, sposób komunikowania się (kapitał strukturalny);

- $\quad$ relacje z użytkownikami biblioteki i jej innymi interesariuszami oraz reputacja w społeczeństwie (kapitał relacyjny).

Wszystkie elementy kapitału intelektualnego współgrające ze sobą są gwarancją wysokiej jakości usług informacyjno-bibliotecznych.

$\mathrm{Z}$ jakością procesów bibliotecznych łączy się występowanie kosztów jakości. Ich rozpoznanie oraz oszacowanie może być przydatne w poprawie jakości usług realizowanych przez biblioteki akademickie. Model Johna Banka przypisuje koszty jakości usługom, w szczególności usługom publicznym. Może on mieć również zastosowanie do usług informacyjno-bibliotecznych. Model strukturalny kosztów jakości według J. Banka zakłada trzy główne kategorie kosztów: koszty zgodności, koszty niezgodności i koszty utraconych korzyści, związane ściśle $z$ niezadowoleniem klientów ${ }^{22}$. Na koszty zgodności składają się koszty profilaktyki (związane z zapobieganiem błędom) i koszty oceny (ponoszone $\mathrm{w}$ związku $\mathrm{z}$ zapewnieniem zgodności ze standardami jakości). Koszty niezgodności obejmują koszty błędów wewnętrznych (wiążące się $\mathrm{z}$ dokonywaniem poprawek $\mathrm{w}$ usługach lub produktach przed ich dostarczeniem zewnętrznemu odbiorcy), koszty błędów zewnętrznych (wiążące się

${ }^{21}$ S. Kasiewicz, W. Rogowski, M. Kicińska, Kapitat intelektualny: spojrzenie z perspektywy interesariuszy, Oficyna Ekonomiczna 2006, s 84-97; J. Samul, Kapitat intelektualny w tworzeniu wartości przedsiębiorstwa - teoria a praktyka, „Economics and Management” 2013, nr 2, s. 234.

${ }^{22}$ J. Bank, Zarządzanie przez jakość, Warszawa 1996, s. 112-130; A. Winnicka-Wejs, Koszty jakości pozyskiwania $i$ rozwoju twórczych pracowników (zastosowanie klasyfikacji J. Banka oraz modelu N. Kano), „Studia Ekonomiczne / Uniwersytet Ekonomiczny w Katowicach" 2012, nr 83, s. 79-80. 
Tabela 1

Adaptacja kosztów jakości według modelu J. Banka do obszaru usług bibliotek akademickich związanych z kształceniem umiejętności informacyjnych użytkowników - propozycja

\begin{tabular}{|c|c|}
\hline $\begin{array}{c}\text { Rodzaj } \\
\text { kosztów jakości }\end{array}$ & $\begin{array}{c}\text { Koszty jakości usług bibliotek akademickich } \\
\text { związanych z kstałceniem umiejętności infor- } \\
\text { macyjnych użytkowników }\end{array}$ \\
\hline \multicolumn{2}{|r|}{ Koszty zgodności } \\
\hline Koszty profilaktyki & $\begin{array}{l}\text { - koszty gromadzenia i przetwarzania informacji o nowych } \\
\text { zbiorach (tradycyjnych i elektronicznych); } \\
\text { - koszty związane z przygotowaniem i prowadzeniem serwisu } \\
\text { internetowego biblioteki; } \\
\text { - koszty związane z opracowaniem oferty szkoleniowej dla } \\
\text { użytkowników. }\end{array}$ \\
\hline Koszty oceny & $\begin{array}{l}\text { - koszty związane z analizą umów związanych z dostępem do } \\
\text { baz danych lub z prenumeratą czasopism. }\end{array}$ \\
\hline \multicolumn{2}{|r|}{ Koszty niezgodności } \\
\hline $\begin{array}{l}\text { Koszty błędów } \\
\text { wewnętrznych }\end{array}$ & $\begin{array}{l}\text { - koszty wynikające z ponownego opracowania zbiorów } \\
\text { (pomyłki w opisie bibliograficznym, sygnatury i lokalizacji } \\
\text { w bibliotece), i temu podobne; } \\
\text { - koszty korekty oferty szkoleniowej lub scenariuszy zajęć dla } \\
\text { użytkowników (materiałów szkoleniowych, zmiany osoby } \\
\text { prowadzącej). }\end{array}$ \\
\hline $\begin{array}{l}\text { Koszty błędów } \\
\text { zewnętrznych }\end{array}$ & $\begin{array}{l}\text { - koszty związane ze źle funkcjonującym katalogiem biblio- } \\
\text { tecznym, systemem do zdalnego korzystania z baz danych } \\
\text { i temu podobne (na przykład ,zawieszanie się" i/lub awarie } \\
\text { systemów informatycznych, skomplikowane procedury logo- } \\
\text { wania) skutkujące niemożnością skorzystania w bibliotece lub } \\
\text { poza nią; } \\
\text { - koszty wynikające ze źle zrealizowanych zamówień w ra- } \\
\text { mach wypożyczeń międzybibliotecznych. }\end{array}$ \\
\hline $\begin{array}{l}\text { Koszty przekroczenia } \\
\text { wymagań }\end{array}$ & $\begin{array}{l}\text { - koszty zbyt wysokich nakładów na intensywną obsługę czy- } \\
\text { telnika (wykonywanie czynności związanych z wyszukiwa- } \\
\text { niem za użytkownika). }\end{array}$ \\
\hline \multicolumn{2}{|r|}{ Koszty utraconych możliwości } \\
\hline \multicolumn{2}{|c|}{$\begin{array}{l}\text { - koszty związane z nieuczestniczeniem w konsorcjach bibliotecznych czy też projektach } \\
\text { umożliwiających pozyskanie zasobów (atrakcyjna i tańsza oferta); } \\
\text { - koszty związane z niewykorzystaniem dodatkowych pakietów powiększających ofertę } \\
\text { biblioteki (na przykład czasopisma w wersji tradycyjnej + wersja elektroniczna; zadbanie } \\
\text { o to, aby pozyskać loginy do prenumerowanych czasopism); } \\
\text { - koszty związane z niedostosowaniem infrastruktury technicznej i informatycznej } \\
\text { (komputery, skanery, systemy zdalnego dostępu, zbyt wolny Internet) do potrzeb środowi- } \\
\text { ska akademickiego; } \\
\text { - koszty wynikające z braku szkoleń dla użytkowników (inne biblioteki zrobią to za nas). }\end{array}$} \\
\hline
\end{tabular}

Źródło: opracowanie własne. 
$\mathrm{z}$ dokonywaniem poprawek $\mathrm{w}$ usługach lub produktach po dostarczeniu ich odbiorcy - wynikają ze zwrotów) i koszty przekroczenia wymagań/oczekiwań (wynikają z dostarczania klientowi nadprogramowych informacji). Koszty straconych korzyści (utraconych możliwości) powodują utratę klientów, a w przypadku organizacji dochodowych - przychodów, wynikają ze złej jakości produktów lub usług.

Przenosząc model Banka na wybrane usługi bibliotek akademickich związane z kształceniem umiejętności informacyjnych użytkowników, niezbędnych w uczestniczeniu w gospodarce opartej na wiedzy, można zaproponować odpowiadające im koszty jakości.

Wysoka jakość usług związanych z kształceniem kompetencji informacyjnych przekłada się na zachowania informacyjne użytkowników. Zachowania te wynikają z potrzeb informacyjnych, mogą być aktywne lub bierne i być związane z procesem pozyskiwania, redagowania i wykorzystywania informacji. Celem procesu kształcenia kompetencji informacyjnych jest między innymi to, aby te zachowania były świadome, kreatywne, celowe i służyły dzieleniu się zdobytą informacją i/lub wiedzą.

\section{Podsumowanie}

W tworzeniu gospodarki opartej na wiedzy bardzo ważną funkcję do spełnienia mają uczelnie wyższe. Oczekiwania wobec sektora nauki wiążą się z procesami tworzenia wiedzy i jej transferu do gospodarki przez wspieranie różnych instytucji, a także z kreowaniem sprzyjającego otoczenia dla tych procesów, jak również łączenia zróżnicowanych zasobów, którymi dysponują uczelnie wyższe, w tym - przede wszystkim - informacyjnych ${ }^{23}$. Wsparciem w tym zakresie są biblioteki akademickie, spełniające szczególną rolę w zakresie kodyfikacji i udostępniania informacji oraz stworzenia warunków do ich pozyskania przez różnych użytkowników. Odpowiedzialność bibliotek akademickich za efektywne kształcenie użytkowników w zakresie obsługi nowoczesnych technologii komunikacyjno-informacyjnych i wykorzystania zasobów elektronicznych jest naturalną konsekwencją wieloletniego doświadczenia w zakresie zarządzania informacją, a tym samym uczestniczenia w budowaniu gospodarki opartej na wiedzy.

\section{Bibliografia}

Bank J., Zarządzanie przez jakość, Warszawa 1996.

Derfert-Wolf L., Information literacy - koncepcje i nauczanie umiejętności informacyjnych, „Biuletyn EBIB” 2005, nr 1(62), [dostęp: 21.03.2015], http://ebib.oss.wroc.p1/2005/62/ derfert.php.

${ }^{23} \mathrm{M}$. Suchacka, Transformacja regionu przemystowego $w$ kierunku regionu wiedzy: studium socjologiczne województwa śląskiego, Katowice 2014, s. 79; K. Leja, Ewolucja uczelni w kierunku organizacji wiedzy, „Współczesne Zarządzanie” 2006, nr 3, s. 110. 
Grala B., Dydaktyka biblioteczna w uczelniach medycznych $w$ aspekcie ksztaltowania się edukacji informacyjnej, „Praktyka i Teoria Informacji Naukowej i Technicznej” 2007, nr 1, s. 31 .

Harvey L., Green D., Defining quality, „Assessment and Evaluation in Higher Education” 1993, Vol. 18, Issue 1, [dostęp: 06.05.2012], http://web.ebscohost.com/ehost/detailvid=4\& hid=106\&sid $=$ c080f621-6f90-4f81 - a1204af89419ea33\%40sessionmgr113\&bdata $=$ Jmxhb mc9cGwmc210ZT1laG9zdC1saXZl\#db=a9h\&AN=9707085278

Jurczak-Pejko E., Kształcenie na poziomie wyższym a potrzeby gospodarki (opartej na) wiedzy, „Studia Ekonomiczne / Uniwersytet Ekonomiczny w Katowicach” 2013, nr 131, s. 105.

Kasiewicz S., Rogowski W., Kicińska M., Kapitat intelektualny: spojrzenie z perspektywy interesariuszy, Kraków 2006.

Konieczko A., Korzyści z ksztatcenia umiejętności informacyjnych użytkowników biblioteki (przykład Biblioteki Głównej Akademii Ekonomicznej im. Karola Adamieckiego w Katowicach, [w:] Seria III: ePublikacje Instytutu INiB UJ, red. Maria Kocójowa, Nr 5. Biblioteka: klucz do sukcesu użtkowników, s. 81, [dostęp: 21.03.2015], http://eprints.rclis.org/ 13696/1/konieczko-n.pdf.

Konieczna D., Ustugi bibliotek akademickich ukierunkowane na potrzeby zdalnego $i$ ustawicznego ksztatcenia, [w:] Nowoczesna Biblioteka Akademicka: Olsztyn 20-21 maja 2004. Dane tekstowe, EBIB Materiały konferencyjne 2004, nr 9, [dostęp: 20.03.2015], http:// www.ebib.pl/publikacje/matkonf/nba/konieczna.danuta.php.

Leja K., Ewolucja uczelni w kierunku organizacji wiedzy, „Współczesne Zarządzanie” 2006, nr 3, s. 110.

Makulska D., Kluczowe czynniki rozwoju w gospodarce opartej na wiedzy, „Prace i Materiały Instytutu Rozwoju Gospodarczego / Szkoła Główna Handlowa” 2012, nr 88, s. 177.

Przybyszewski R.: Kapital ludzki w procesie kształtowania gospodarki opartej na wiedzy, Warszawa 2007.

Resort nauki: w 2015 r. nakłady na naukę wyższe o 690 mln zt., [dostęp: 08.04.2015], Serwis Nauka w Polsce http://naukawpolsce.pap.pl.

Samul J., Kapital intelektualny w tworzeniu wartości przedsiębiorstwa - teoria a praktyka, „Economics and Management” 2013, nr 2, s. 234.

Skórska A., Wiedzochłonne ustugi biznesowe w Polsce i innych krajach Unii Europejskiej, Katowice 2012.

Skrzypek E., Hofman M., Zarządzanie procesami w przedsiębiorstwie. Identyfikacja, pomiar, usprawnianie, Warszawa 2010.

Suchacka M., Transformacja regionu przemystowego w kierunku regionu wiedzy: studium socjologiczne województwa śląskiego, Katowice 2014.

Toffler A., Trzecia fala, Poznań 2006.

Uniwersalny stownik języka polskiego, red. S. Dubisz, Warszawa 2003.

Vargo S.L., Lusch R.F., Evolving to a new dominant logic for marketing, „Journal of Marketing" 2004 , t. 68 , nr 1, s. 2.

Winnicka-Wejs A., Koszty jakości pozyskiwania $i$ rozwoju twórczych pracowników (zastosowanie klasyfikacji J. Banka oraz modelu N. Kano), „Studia Ekonomiczne / Uniwersytet Ekonomiczny w Katowicach" 2012, nr 83, s. 79-80.

Ziemba E., Żelazny R., Społeczeństwo informacyjne - projekty i przedsięwzięcia w województwie śląskim, „Nierówności Społeczne a Wzrost Gospodarczy / Uniwersytet Rzeszowski” 2013, nr 32, s. 555.

Zybert E.B., Jakość w działalności bibliotek. Oceny, pomiary, narzędzia, Warszawa 2007.

Zybert E.B., Wstęp, [w:] Czas przemian, czas wyzwań: rola bibliotek i ośrodków informacji w procesie kształtowania kompetencji współczesnego człowieka, red. J. Jasiewicz, E.B. Zybert, Warszawa 2014. 